Correspondence: Valeriu Plesca, National Agency of Public Health, Chisinau, Republic of Moldova.

Tel. +373.69.108145

E-mail:vplesca@gmail.com

Key words: Multidrug-resistant tuberculosis; catastrophic cost; treatment outcome; Republic of Moldova; SORT-TB.

Acknowledgements: The authors thank the national tuberculosis counterparts Institute of Phthisiopneumology "Chiril Draganiuc" and National Agency of Public Health (Republic of Moldova) for defining research questions and providing data for this study. It is also worth mentioning Kostyantyn Dumchev (Institute on Public Health, Kyiv, Ukraine) for his contribution to the data analysis stage. In addition, the authors thank the the UNICEF/UNDP/World Bank/WHO Special Programme for Research and Training in Tropical Diseases (TDR) for supporting the baseline study. The authors thank the secretariat of the European TB Research Initiative (ERI-TB) at the WHO Regional Office for Europe for organizing the Structured Operational Research Training (SORT-TB) for eastern European countries supported by the USAIDWHO regional partnership project to End TB in eastern Europe. SORT-TB curriculum was an adaptation of the TDR's SORT IT course (https://www.who.int/tdr/capacity/strengthening/sort/en/) to the eastern European context

Contributions: VP, AC, YS, AD, conceived the study aims. All authors participated in the design, discussion of the results interpretation, read, edited, and agreed with the decision to submit the final version of the paper. VP led the data collection and reference reviews. VP, AC, YS, AD, designed and executed the analysis; VP wrote the first draft of the manuscript; AC, $\mathrm{YS}, \mathrm{AD}$, provided revisions to the initial version of the manuscript. All authors approved the final version of the paper submitted to the journal.

Conflict of interest: The authors declare no conflict of interest.

Funding: This study was funded by the United States Agency for International Development (USAID). The funder played no role in the study design, data collection and analysis, decision to publish or preparation of the manuscript.

Ethics approval: Permission for this research was obtained from the National Committee for Ethical Expertise of Clinical Trial of the Republic of Moldova. An ethics exemption was also obtained from the World Health Organization Research Ethics Review Committee based in Geneva, Switzerland (ERC.0003311/09.03.2020). A waiver of informed consent was granted by ethics review bodies, as the study collected and analysed secondary research data and de-identified routine recording and reporting data.

Disclaimer: The authors alone are responsible for the views expressed in this publication and they do not necessarily represent the decisions or policies of the World Health Organization.

Received for publication: 10 July 2020.

Accepted for publication: 11 August 2020.

(World Health Organization 2021.

All rights reserved. The WHO Regional Office for Europe has granted the Publisher permission for the reproduction of this article.

Licensee PAGEPress, Italy

Monaldi Archives for Chest Disease 2021; 91:1650

doi: 10.4081 /monaldi.2021.1650

Open access statement: In accordance with WHO's open-access publication policy for all work funded by WHO or authored/co-authored by WHO staff members, the WHO retains the copyright of this publication through a Creative Commons Attribution IGO licence (http://creativecommons.org/licenses/by/3.0/igo/legalcode) which permits unrestricted use, distribution and reproduction in any medium provided the original work is properly cited.

\section{Do catastrophic costs impact treatment outcomes in people with rifampicin-resistant tuberculosis in the Republic of Moldova?}

\author{
Valeriu Plesca ${ }^{1}$, Ana Ciobanu ${ }^{2,3}$, Yuliia Sereda ${ }^{3}$, \\ Andrei Dadu ${ }^{3}$
}

${ }^{1}$ National Agency of Public Health, Chisinau, Republic of Moldova; ${ }^{2}$ Health Primary Care Department, University of Medicine and Pharmacy N. Testemitanu, Chisinau, Republic of Moldova; ${ }^{3}$ World Health Organization, Regional Office for Europe, Copenhagen, Denmark

\section{Abstract}

The Republic of Moldova is among the 30 rifampicin-resistant and/or multidrug-resistant (RR/MDR) tuberculosis (TB) high burden countries in the world. Despite free TB diagnostics and treatment, TB patients face substantial economic losses and this may impact overall treatment outcomes. We assessed if there is an association between TB-related catastrophic costs and TB treatment outcomes. We conducted a cohort study using data from patient records and a survey that quantified catastrophic costs among RR/MDR-TB affected households in the Republic of Moldova in 2016. We included adult patients (age $\geq 18$ years) with RR/MDR-TB who had been in inpatient (intensive phase) or outpatient (continuous phase) treatment for at least 2 months. Unfavourable treatment outcome, such as failure, death or lost to follow-up, was the primary outcome variable. The definition of catastrophic TB-related costs followed the World Health Organisation (WHO) guidelines: costs due to $\mathrm{TB} \geq 20 \%$ of annual household income. Log-binomial regression was used to assess association between the outcome and catastrophic TB-related costs adjusting for other socio-demographic, behavioural and clinical covariates. In total $287 \mathrm{RR} / \mathrm{MDR}-\mathrm{TB}$ patients $(78 \%$ males, mean age 42 years) were included. Of them, 30\% experienced catastrophic TB-related costs. Overall, one in five patients $(21 \%)$ had unfavourable treatment outcome, such as treatment failure $(5 \%)$, death $(8 \%)$ or lost to follow-up $(8 \%)$. The experience of catastrophic TB-related costs was not associated with unfavourable treatment outcome [adjusted relative risk $(\mathrm{aRR})=0.88,95 \% \mathrm{CI}$ : $0.50-1.50]$. Major factors independently associated with unfavourable TB treatment outcomes were poverty $(\mathrm{aRR}=2.07$; 95\% CI: 1.06-4.07), urban residence ( $\mathrm{aRR}=1.99$; 95\% CI: 1.12 3.52) and positive HIV (Human Immunodeficiency Virus) status $(\mathrm{aRR}=2.61 ; 95 \% \mathrm{CI}: 1.31-4.89)$. As a result, we failed to find an association between catastrophic costs and treatment outcomes of RR/MDR-TB patients in the Republic of Moldova. However, we found that patients from poor households and urban areas were twice more likely to achieve unfavourable TB treatment outcomes disregarding whether they experienced catastrophic costs or not. Also, TB/HIV patients and urban residents were identified as the most vulnerable groups with higher risk of unfavourable treatment outcome and TB-related costs. 


\section{Introduction}

Globally, about 400 million people lack access to one of seven essential services for Millennium Development Goal priority areas annually [1,2]. It is estimated that over 100 million people fall below the poverty line every year as a result of out-of-pocket expenditures on health [3] and about 150 million people suffer catastrophic health expenditure because they pay for health services [4]. Universal health coverage, along with cutting down the socioeconomic burden to eliminate the catastrophic costs incurred by tuberculosis (TB)-affected households, and interventions to improve quality of life for patients while enabling adherence to treatment are key objectives of the World Health Organisation (WHO) End TB Strategy 2016-2035 [5]. WHO defined catastrophic cost as costs exceeding $20 \%$ of annual household income and which are incurred during patients' pre-diagnostic, diagnostic, and treatment stages [6].

The Republic of Moldova is a lower-middle-income country where $44 \%$ of current health expenditure are paid out-of-pocket $[7,8]$. It is among the countries in Europe that is facing the most economic difficulties [8] contributing to poverty and public health challenges, including TB. As is it known TB often results in severe economic consequences for TB-affected households [9]. The burden of TB places the country among the 18 high-priority countries in the WHO European Region and among 30 countries with a high Rifampicin-Resistant or Multi-Drug-Resistance (RR/MDR) TB burden in the world [10]. Besides, it is among 8 countries of the East Europe and central Asia (Azerbaijan, Kyrgyzstan, Republic of Moldova, Romania, Russian Federation, Tajikistan, Ukraine, and Uzbekistan) showing significant increases in trends of RR/MDRTB among new TB patients [11].

The country has taken substantial steps to improve TB care in the last two decades, by implementing reforms according to international recommendations $[5,12,13]$. These efforts improved the key impact indicators such as TB mortality and TB notification rate which decreased respectively by $66 \%$ (from 18 to 6 per 100,000 ) and $38 \%$ (from 113 to 72 per 100,000 ) from 2010 to 2019 $[14,15]$. However, the treatment success rate among MDR-TB patients remains low (55\%) and has not reached the target of $75 \%$ for WHO European region $[12,15]$.

TB diagnosis and TB treatment are free of charge in the Republic of Moldova. Nevertheless, TB patients may face medical costs during the pre-diagnostic stage if they are not insured for health, for high-performance procedures (magnetic resonance tomography, computed tomography etc.), for private medicine, for treatment of side effects, especially in the ambulatory stage of TB treatment, and for co-morbidities (except HIV). Non-medical financial burden is a result of inability to work during TB treatment or limited support from the family. To address these barriers in the Republic of Moldova, a system of incentives for TB patients was introduced in 2009 and universal coverage was achieved in 2011. Still, a survey conducted in 2016 showed that catastrophic costs were experienced by $26 \%$ of households at over $20 \%$ cut-off value of annual household income, and by $7 \%$ of households at over $40 \%$ cut-off value [16].

These findings are in line with evidence from other parts of the word which quantified the costs associated to TB and identified various barriers in terms of access to health care but none examined the relationship between catastrophic costs and treatment outcomes [17-23].

Taking into account the high RR/MDR-TB burden in the Republic of Moldova, suboptimal treatment outcomes and high level of catastrophic costs while accessing health care, we decided to assess the association between treatment outcomes and costs related to TB. We hypothesized that RR/MDR-TB patients with catastrophic TB-related costs were more likely to have unfavourable TB treatment outcomes.

\section{Methods}

\section{Study design}

This is a cohort study following-up the TB patients identified in a survey on TB-related costs conducted in 2016 [16]. The baseline study was a cross-sectional assessment of direct and indirect costs incurred by the households with RR/MDR-TB patients. At the end of 2018, we extracted TB treatment details and outcomes of patients enrolled in the baseline study and merged them with the data on costs.

\section{General setting}

The Republic of Moldova is situated in the South eastern Europe, bordering Romania and Ukraine. The part of the country, informally referred to as the Left Bank of the Dniester River, is not controlled by official authorities. The Right Bank of the Dniester River has a total population of about 3 million and has a population density of 90 people per square kilometre.

\section{National TB control}

The primary responsibility for TB care and control in the Republic of Moldova lies with the Ministry of Health, Labour and Social Protection. TB care services are implemented by the National Tuberculosis Program (NTP), in collaboration with other governmental entities, development partners and civil society organizations. The diagnosis and management of TB are in accordance with WHO guidelines [24]. There is a national TB casebased database in the country - Information System for Monitoring and Evaluation TB patients (SIME TB) - for TB patients' notification and their follow-up [15]. Welfare benefits are available in the Republic of Moldova for RR/MDR-TB patients, including temporary disability allowances and incentives provided to patients adhering to treatment during outpatient care. Various incentive systems have been in place over the years [25]. During the baseline study period, outpatient RR/MDR-TB patients received adherence incentives for $90 \%$ of doses taken (20 USD per month before $1^{\text {st }}$ of July 2015 and 56 USD per month in period after $1^{\text {st }}$ of July 2015 (Supplementary Table 1).

\section{Study population}

The baseline study (June-November 2016) included 287 adult ( $\geq 18$ years) RR/MDR-TB patients who had undergone inpatient care for at least 2 months during the intensive phase (150 patients) and outpatient care for at least two months during the continuation phase (137 patients). Patients from Left Bank of the Dniester River and incarcerated patients were excluded. RR-TB patients have infections that are resistant to rifampicin (RIF), while MDR-TB patients have infections resistant to at least rifampicin (RIF) and isoniazid (INH), confirmed by culture, line probe assay, or any other drug susceptibility test.

\section{Data sources and variables}

We used two data sources: i) the baseline survey conducted in 2016 (socio-demographical characteristics of patients, quantifica- 
tion of income and catastrophic costs) [16], and ii) national database - SIME TB (treatment outcomes and clinical characteristics of patients).

TB treatment outcome and catastrophic cost definitions were in line with WHO guidelines. We considered treatment cure or completion as favourable treatment outcome and failure, death or loss to follow-up as unfavourable outcome. Household income was categorized by Wealth Index, based on Multiple Indicator Cluster Surveys methodology [26]. We also included a variable based on World Bank definition of poverty, such as an income of $\leq 1.90$ USD per capita per day [27]. Catastrophic TB-related costs were defined as $\geq 20 \%$ of annual income for TB-affected households. Details on costs (direct, indirect, welfare benefits) and definitions for other variables are provided in Supplementary Table 1.

\section{Data analysis}

The survey data were entered into IBM ${ }^{\circledR}$ SPSS $\AA$ Statistics (version 20.0). Clinical data exported from SIME TB was merged with SPSS database by the Patient ID. Final dataset was checked for consistency with original data sources. Analysis was done using R, version 3.5.2 software ( ${ }^{\circ} \mathrm{R}$ Foundation for Statistical Computing, 2016). We described patients' characteristics with frequencies and percentages for categorical variables and mean (and standard deviation) or median (and interquartile range) for continuous variables, as appropriate. Patients' profile was stratified by the experience of TBrelated catastrophic costs and we measured differences using Chisquare tests for categorical variables and $t$-tests for continuous variables. If expected cell frequency was less than 5, Fisher's exact test was used instead of Chi-square test. $t$-test was replaced with Kruskal-Wallis test for continuous variables deviating from the nor-

Table 1. Socio-demographic, behavioural and clinical characteristics of RR/MDR-TB patients with and without TB-related catastrophic costs, Republic of Moldova, 2016.

\begin{tabular}{|c|c|c|c|c|}
\hline Characteristics & $\begin{array}{l}\text { Total } \\
(\%) \\
\\
287\end{array}$ & $\begin{array}{c}\text { Percent } \\
\text { from the } \\
\leq 19 \% \\
\text { n }(\%) \\
201\end{array}$ & $\begin{array}{l}\text { ted costs } \\
\mathrm{d} \text { income } \\
\geq 20 \% \\
\text { n (\%) } \\
86\end{array}$ & p-value $^{\circ}$ \\
\hline $\begin{array}{l}\text { Sex } \\
\text { Male } \\
\text { Female }\end{array}$ & $\begin{array}{c}225(78.4) \\
62(21.6)\end{array}$ & $\begin{array}{c}159(70.7) \\
42(67.7)\end{array}$ & $\begin{array}{l}66(29.3) \\
20(32.3)\end{array}$ & 0.773 \\
\hline Mean age (standard deviation), years & $42(12)$ & $42(12)$ & $41(12)$ & 0.585 \\
\hline $\begin{array}{l}\text { Age group, years } \\
18-44 \\
45-78\end{array}$ & $\begin{array}{l}175(61.0) \\
112(39.0)\end{array}$ & $\begin{array}{c}125(71.4) \\
76(67.9)\end{array}$ & $\begin{array}{l}50(28.6) \\
36(32.1)\end{array}$ & 0.609 \\
\hline $\begin{array}{l}\text { Type of residence } \\
\text { Urban } \\
\text { Rural }\end{array}$ & $\begin{array}{l}103(35.9) \\
184(64.1)\end{array}$ & $\begin{array}{c}70(68.0) \\
131(71.2)\end{array}$ & $\begin{array}{l}33(32.0) \\
53(28.8)\end{array}$ & 0.660 \\
\hline $\begin{array}{l}\text { Household size, persons } \\
1 \\
2-3 \\
4-9\end{array}$ & $\begin{array}{c}56(19.5) \\
138(48.1) \\
93(32.4)\end{array}$ & $\begin{array}{l}35(62.5) \\
98(71.0) \\
68(73.1)\end{array}$ & $\begin{array}{l}21(37.5) \\
40(29.0) \\
25(26.9)\end{array}$ & 0.368 \\
\hline $\begin{array}{l}\text { Household in the poverty, World Bank criterion } \\
\leq 1.90 \text { USD per person per day } \\
>1.90 \text { USD per person per day }\end{array}$ & $\begin{array}{l}146(50.9) \\
141(49.1)\end{array}$ & $\begin{array}{c}97(66.4) \\
104(73.8)\end{array}$ & $\begin{array}{l}49(33.6) \\
37(26.2)\end{array}$ & 0.221 \\
\hline $\begin{array}{l}\text { Wealth index } \\
\text { Poorest } \\
\text { Poor } \\
\text { Middle } \\
\text { Rich } \\
\text { Richest }\end{array}$ & $\begin{array}{l}57(19.9) \\
58(20.2) \\
57(19.9) \\
58(20.2) \\
57(19.8)\end{array}$ & $\begin{array}{l}40(70.2) \\
40(69.0) \\
41(71.9) \\
42(72.4) \\
38(66.7)\end{array}$ & $\begin{array}{l}17(29.8) \\
18(31.0) \\
16(28.1) \\
16(27.6) \\
19(33.3)\end{array}$ & 0.964 \\
\hline $\begin{array}{l}\text { Married or cohabitation } \\
\text { Yes } \\
\text { No }\end{array}$ & $\begin{array}{l}148(51.6) \\
139(48.4)\end{array}$ & $\begin{array}{c}109(73.6) \\
92(66.2)\end{array}$ & $\begin{array}{l}39(26.4) \\
47(33.8)\end{array}$ & 0.211 \\
\hline $\begin{array}{l}\text { Education } \\
\text { Primary or no education } \\
\text { Secondary } \\
\text { Secondary professional / Higher }\end{array}$ & $\begin{array}{l}103(35.9) \\
138(48.1) \\
46(16.0)\end{array}$ & $\begin{array}{l}72(69.9) \\
98(71.0) \\
31(67.4)\end{array}$ & $\begin{array}{l}31(30.1) \\
40(29.0) \\
15(32.6)\end{array}$ & 0.897 \\
\hline $\begin{array}{l}\text { Employment } \\
\text { Officially employed } \\
\text { Unofficially employed or not employed }\end{array}$ & $\begin{array}{l}117(40.8) \\
170(59.2)\end{array}$ & $\begin{array}{c}93(79.5) \\
108(63.5)\end{array}$ & $\begin{array}{l}24(20.5) \\
62(36.5)\end{array}$ & 0.006 \\
\hline $\begin{array}{l}\text { Labor migration } \\
\text { Yes } \\
\text { No }\end{array}$ & $\begin{array}{c}50(17.4) \\
237(82.6)\end{array}$ & $\begin{array}{c}40(80.0) \\
161(67.9)\end{array}$ & $\begin{array}{l}10(20.0) \\
76(32.1)\end{array}$ & 0.128 \\
\hline
\end{tabular}

To be continued on next page 
mal distribution. Relative risk was selected as a measure of association in the analysis of treatment outcome factors. We calculated unadjusted and adjusted relative risks and their confidence intervals using log-binomial regressions. The adjusted model included factors associated with the outcome at $\mathrm{p}<0.1$ in binary regressions and age and sex disregarding their significance as common confounders. We also consecutively measured interactions between TB-related catastrophic costs and other selected covariates, so that the effect of TBrelated catastrophic costs on TB treatment outcome was allowed to vary depending on the value of other variables. Significance of interactions was measured by Wald tests. Considering that catastrophic TB-related costs could be on the causal pathway between income and treatment outcomes, we calculated proportion of patients with unfavourable outcome stratified by the experience of catastrophic costs and wealth index, and measured the association by the Mantel-
Haenszel Chi-square test. Levels of significance throughout the analysis was set at $5 \%$.

\section{Results}

A total of 287 RR/MDR-TB patients were included in the analysis. Mean age was 42 (SD 12) years; most of them were male $(225 / 287,78 \%)$ and lived in a rural area $(184 / 287,64 \%)$ (Table 1). Over half of patients $(146 / 287,51 \%)$ came from the households living below the poverty line as per the World Bank definition. According to the Wealth Index, 115 (40\%) patients belonged to the poorest or poor households. Median percentage of TB-related costs from the household income was 15\% (inter-quartile range: 9-22\%).

Table 1. Continued from previous page.

\begin{tabular}{|c|c|c|c|c|}
\hline Characteristics & $\begin{array}{l}\text { Total } \\
(\%) \\
287\end{array}$ & $\begin{array}{c}\text { Percent } \\
\text { from the } \\
\leq 19 \% \\
\text { n ( } \%) \\
201\end{array}$ & $\begin{array}{l}\text { ted costs } \\
\geq 20 \% \\
\text { n ( } \%) \\
86\end{array}$ & p-value ${ }^{\circ}$ \\
\hline $\begin{array}{l}\text { Medical insurance status before TB* } \\
\text { Yes } \\
\text { No }\end{array}$ & $\begin{array}{l}127(45.0) \\
155(55.0)\end{array}$ & $\begin{array}{c}88(69.3) \\
108(69.7)\end{array}$ & $\begin{array}{l}39(30.7) \\
47(30.3)\end{array}$ & 1.000 \\
\hline $\begin{array}{l}\text { History of imprisonment* } \\
\text { Yes } \\
\text { No }\end{array}$ & $\begin{array}{c}31(11.2) \\
246(88.8)\end{array}$ & $\begin{array}{c}18(58.1) \\
178(72.4)\end{array}$ & $\begin{array}{l}13(41.9) \\
68(27.6)\end{array}$ & 0.150 \\
\hline $\begin{array}{l}\text { Excessive alcohol consumption } \\
\text { Yes } \\
\text { No }\end{array}$ & $\begin{array}{c}32(11.1) \\
255(88.9)\end{array}$ & $\begin{array}{c}22(68.8) \\
179(70.2)\end{array}$ & $\begin{array}{l}10(31.2) \\
76(29.8)\end{array}$ & 1.000 \\
\hline $\begin{array}{l}\text { HIV status } \\
\text { Negative } \\
\text { Positive }\end{array}$ & $\begin{array}{c}262(91.3) \\
25(8.7)\end{array}$ & $\begin{array}{c}182(69.5) \\
19(76.0)\end{array}$ & $\begin{array}{c}80(30.5) \\
6(24.0)\end{array}$ & 0.651 \\
\hline $\begin{array}{l}\text { Presence of diabetes mellitus } \\
\text { Yes } \\
\text { No }\end{array}$ & $\begin{array}{c}8(2.8) \\
279(97.2)\end{array}$ & $\begin{array}{c}3(37.5) \\
198(71.0)\end{array}$ & $\begin{array}{c}5(62.5) \\
81(29.0)\end{array}$ & 0.055 \\
\hline $\begin{array}{l}\text { Type of TB case } \\
\text { New } \\
\text { Retreatment }\end{array}$ & $\begin{array}{l}189(65.9) \\
98(34.1)\end{array}$ & $\begin{array}{l}128(67.7) \\
73(74.5)\end{array}$ & $\begin{array}{l}61(32.3) \\
25(25.5)\end{array}$ & 0.294 \\
\hline $\begin{array}{l}\text { Presence of side-effects during TB treatment } \\
\text { Yes } \\
\text { No }\end{array}$ & $\begin{array}{c}244(85.0) \\
43(15.0)\end{array}$ & $\begin{array}{l}171(70.1) \\
30(69.8)\end{array}$ & $\begin{array}{l}73(29.9) \\
13(30.2)\end{array}$ & 1.000 \\
\hline $\begin{array}{l}\text { Perceived needs - family support* } \\
\text { Yes } \\
\text { No }\end{array}$ & $\begin{array}{l}150(55.4) \\
121(44.6)\end{array}$ & $\begin{array}{l}106(70.7) \\
83(68.6)\end{array}$ & $\begin{array}{l}44(29.3) \\
38(31.4)\end{array}$ & 0.813 \\
\hline $\begin{array}{l}\text { Perceived needs - better alimentation* } \\
\text { Yes } \\
\text { No }\end{array}$ & $\begin{array}{c}210(77.5) \\
61(22.5)\end{array}$ & $\begin{array}{c}145(69.0) \\
44(72.1)\end{array}$ & $\begin{array}{l}65(31.0) \\
17(27.9)\end{array}$ & 0.762 \\
\hline $\begin{array}{l}\text { Perceived treatment barriers - smoking* } \\
\text { Yes } \\
\text { No }\end{array}$ & $\begin{array}{l}117(44.0) \\
149(56.0)\end{array}$ & $\begin{array}{c}82(70.1) \\
103(69.1)\end{array}$ & $\begin{array}{l}35(29.9) \\
46(30.9)\end{array}$ & 0.973 \\
\hline $\begin{array}{l}\text { Perceived treatment barriers - side effects* } \\
\text { Yes } \\
\text { No }\end{array}$ & $\begin{array}{l}127(47.7) \\
139(52.3)\end{array}$ & $\begin{array}{l}90(70.9) \\
95(68.3)\end{array}$ & $\begin{array}{l}37(29.1) \\
44(31.7)\end{array}$ & 0.754 \\
\hline $\begin{array}{l}\text { Perceived concerns - treatment without effect* } \\
\text { Yes } \\
\text { No }\end{array}$ & $\begin{array}{l}115(48.9) \\
120(51.1)\end{array}$ & $\begin{array}{l}78(67.8) \\
81(67.5)\end{array}$ & $\begin{array}{l}37(32.2) \\
39(32.5)\end{array}$ & 1.000 \\
\hline $\begin{array}{l}\text { Perceived concerns - spread TB to my family* } \\
\text { Yes } \\
\text { No }\end{array}$ & $\begin{array}{l}115(48.9) \\
120(51.1)\end{array}$ & $\begin{array}{l}74(64.3) \\
85(70.8)\end{array}$ & $\begin{array}{l}41(35.7) \\
35(29.2)\end{array}$ & 0.356 \\
\hline
\end{tabular}

${ }^{\circ}$ Chi-square tests for categorical variables and t-test for age: missing data was excluded during hypothesis testing; *missing data was excluded: medical insurance status before TB ( $\mathrm{n}=2$ ); history of imprisonment $(\mathrm{n}=8)$; perceived needs - family support or better alimentation $(\mathrm{n}=15)$; perceived treatment barriers - smoking or side effects ( $\mathrm{n}=20)$; perceived concerns - treatment without effect or spread TB to my family $(\mathrm{n}=45)$; TB, tuberculosis; RR/MDR-TB, rifampicin resistant or multi-drug resistant tuberculosis; HIV, human immunodeficiency viruses. 
One-third of patients $(86 / 287,30 \%)$ experienced catastrophic TBrelated costs. The proportion of patients with catastrophic costs was higher among unofficially employed or unemployed (62/170, $37 \%)$ compared to employed $(24 / 117,21 \%, \mathrm{p}=0.006)$. There was no difference by other variables.

In the survey, most of the patients $(210 / 287,78 \%)$ emphasized unmet needs for better alimentation, and over half of the sample $(150 / 287,55 \%)$ needed more family support. Patients considered side effects $(127 / 287,48 \%)$ and smoking $(117 / 287,44 \%)$ as major treatment barriers. Nearly half of the study participants $(115 / 287$, $49 \%$ ) had concerns that TB treatment would not be successful. Perceived needs, barriers and concerns were not associated with the experience of catastrophic TB-related costs.

Of the 287 patients, $60(21 \%)$ had unfavourable treatment outcome, such as treatment failure $(15 / 287,5 \%)$, death $(22 / 287,8 \%)$ or loss to follow-up $(23 / 287,8 \%)$. In the unadjusted analysis, the experience of catastrophic TB-related costs was not associated with unfavourable outcome [relative risk $(R R)=0.92,95 \%$ confidence interval (CI): 0.54-1.49] (Table 2). Proportion of unfavourable treatment outcomes was $20 \%(17 / 86)$ among patients with catastrophic TB-related costs and 21\% (43/201) among patients with non-catastrophic costs $(\mathrm{p}=0.756)$ (Table 3$)$. In analy- sis adjusted for sex, age, material status, type of residence, and HIV comorbidity, the link between catastrophic TB-related costs and unfavourable outcome remained insignificant [adjusted RR $(\mathrm{aRR})=0.90,95 \% \mathrm{CI}: 0.50-1.56]$. We did not find an interaction between TB catastrophic costs and wealth. In both groups of patients with and without catastrophic costs, poor patients had higher proportion of unfavourable treatment outcome than patients from middle/rich income groups (Figure 1).

Major factors independently associated with unfavourable TB treatment outcomes were poverty by the Wealth index $(\mathrm{aRR}=2.07$; 95\% CI: 1.06-4.07), urban residence ( $\mathrm{aRR}=1.99$; 95\% CI: $1.12-$ 3.52 ) and positive HIV status (aRR=2.61; 95\% CI: $1.31-4.89)$.

\section{Discussion}

This research is a continuation of the baseline study where TBrelated costs were quantified [16] for the Republic of Moldova. Besides, this is the first study assessing the association between catastrophic costs and treatment outcomes in the country and in the WHO European Region. Contrary to our expectation, we found no

Table 2. Treatment outcomes of RR/MDR-TB patients with and without TB-related catastrophic costs, Republic of Moldova, 2016.

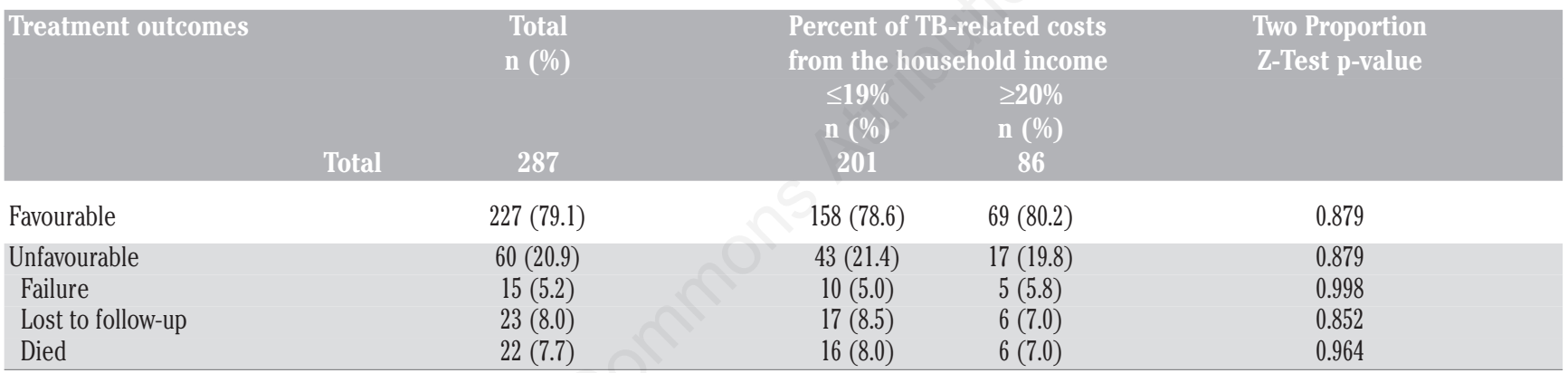

TB, tuberculosis; RR/MDR-TB, rifampicin resistant or multi-drug resistant tuberculosis.

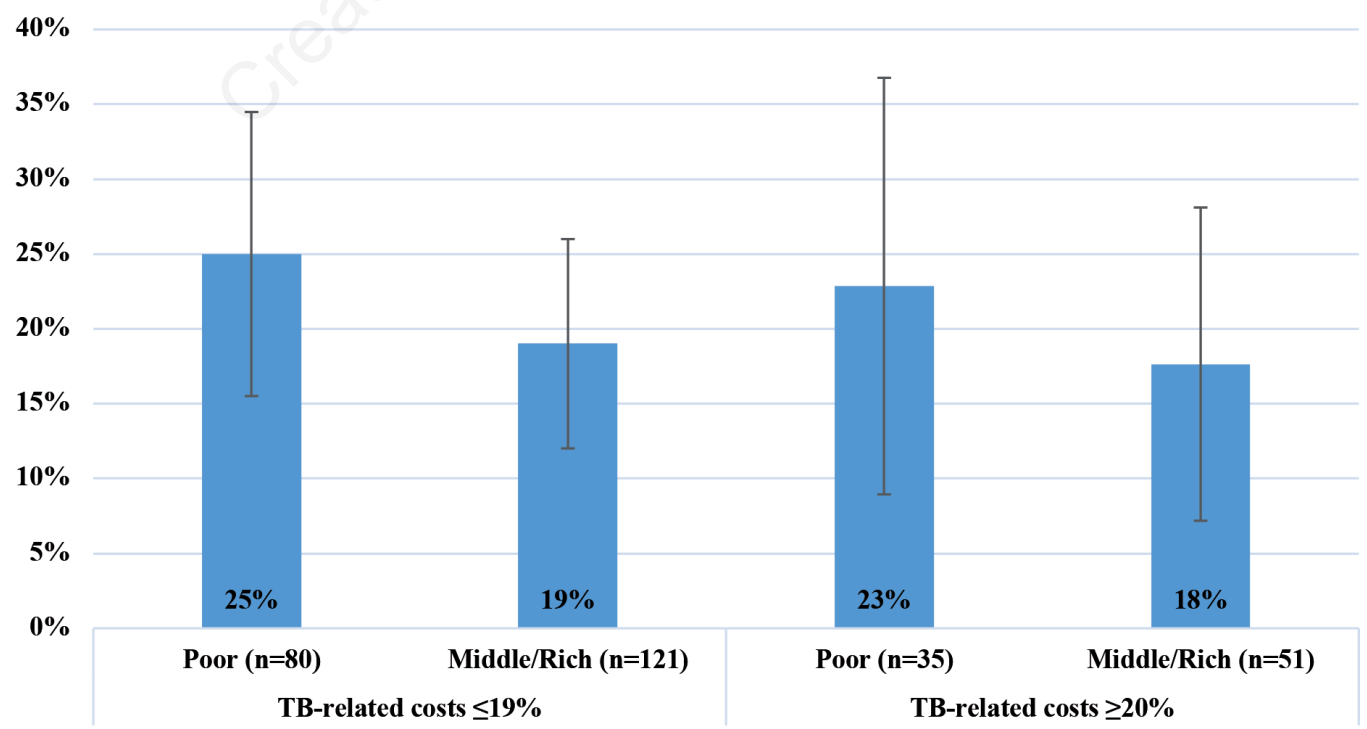

Figure 1. Proportion of unfavourable TB treatment outcomes by the Wealth index groups and experience of catastrophic TB-related costs $(\geq 20 \%)$, Republic of Moldova, 2016. Mantel-Haenszel Chi-squared test for the stratified table: $p=0.306$. 
association between catastrophic costs and unfavourable TB outcome in this setting. In contrast, a study from Peru identified an association between the costs and RR/MDR-TB in similar proportions of unfavourable outcomes [28].

Several factors were associated with unfavourable TB treatment outcomes in our study, and primarily poverty. A study conducted in Georgia among susceptible TB patients found that patients with lower household income were at greater risk of unfavourable TB treatment outcomes [29]. We can explain this with the fact that treatment of RR/MDR-TB is complex and prolonged over time. Thus, poverty caused by health-related payments could rise sharply in poorer households. Far more, temporary disability due to TB, as well as TB-related costs experienced in accessing diagnostic and treatment services, worsen their financial situation, affecting the well-being of patients and households, which are actually the main factors of poverty and both can lead to adverse outcomes of TB. Another explanation can be that TB patients who come from the poorest households and have a low welfare level are not able to face health expenditure, for diagnosis as well as for treatment. In the Republic of Moldova usually, people from poor households do not seek medical care in the same way as the wealthier [30]. Hereby, this can lead to delayed diagnosis and TB treatment, and, of course, to non-adherence with the long-term treatment regimen for RR/MDR-TB. Besides, people with low welfare level have less satisfactory living conditions compared to those who have higher welfare level. At the same

Table 3. Associated factors contributing to unfavourable outcomes among RR/MDR-TB patients who experienced TB-related catastrophic costs, Republic of Moldova, 2016.

\begin{tabular}{|c|c|c|c|c|}
\hline Characteristics & $\begin{array}{l}\text { TB treatn } \\
\text { Favourable } \\
\text { n (\%) } \\
227\end{array}$ & $\begin{array}{l}\text { Unfavourable } \\
\text { n (\%) } \\
60\end{array}$ & $\begin{array}{c}\text { RR } \\
{[95 \% \mathrm{CI}]}\end{array}$ & $\begin{array}{c}\text { Adjusted RR } \\
\text { [95\% CI] }\end{array}$ \\
\hline $\begin{array}{l}\text { Sex } \\
\text { Male } \\
\text { Female }\end{array}$ & $\begin{array}{l}175(77.8) \\
52(83.9)\end{array}$ & $\begin{array}{l}50(22.2) \\
10(16.1)\end{array}$ & $\begin{array}{c}1.38[0.78 ; 2.74] \\
\text { ref. }\end{array}$ & $\begin{array}{c}1.57[0.82 ; 3.31] \\
-\end{array}$ \\
\hline $\begin{array}{l}\text { Age group, years } \\
18-44 \\
45-78\end{array}$ & $\begin{array}{l}135(77.1) \\
92(82.1)\end{array}$ & $\begin{array}{l}40(22.9) \\
20(17.9)\end{array}$ & $\begin{array}{c}\text { ref. } \\
0.78[0.47 ; 1.25]\end{array}$ & $\begin{array}{c}\text { ref. } \\
0.88[0.50 ; 1.50]\end{array}$ \\
\hline $\begin{array}{l}\text { Percent of TB-related costs from the household income } \\
\leq 19 \% \\
\geq 20 \%\end{array}$ & $\begin{array}{c}158(78.6) \\
69(80.2)\end{array}$ & $\begin{array}{l}43(21.4) \\
17(19.8)\end{array}$ & $\begin{array}{c}\text { ref. } \\
0.92[0.54 ; 1.49]\end{array}$ & $\begin{array}{c}\text { ref. } \\
0.90[0.50 ; 1.56]\end{array}$ \\
\hline $\begin{array}{l}\text { Type of residence } \\
\text { Urban } \\
\text { Rural }\end{array}$ & $\begin{array}{c}75(72.8) \\
152(82.6)\end{array}$ & $\begin{array}{l}28(27.2) \\
32(17.4)\end{array}$ & $\begin{array}{c}1.56[0.99 ; 2.44] \\
\text { ref. }\end{array}$ & $\begin{array}{c}1.99 \text { [1.12;3.52] } \\
\text { ref. }\end{array}$ \\
\hline $\begin{array}{l}\text { Household size, persons } \\
1 \\
2-3 \\
4-9\end{array}$ & $\begin{array}{l}41(73.2) \\
109(79.0) \\
77(82.8)\end{array}$ & $\begin{array}{l}15(26.8) \\
29(21.0) \\
16(17.2)\end{array}$ & $\begin{array}{l}1.56[0.83 ; 2.92] \\
1.22[0.71 ; 2.18] \\
\text { ref. }\end{array}$ & $\begin{array}{l}- \\
- \\
-\end{array}$ \\
\hline $\begin{array}{l}\text { Household in the poverty by the World Bank criterion } \\
\leq 1.90 \text { USD per person per day } \\
>1.90 \text { USD per person per day }\end{array}$ & $\begin{array}{l}115(78.8) \\
112(79.4)\end{array}$ & $\begin{array}{l}31(21.2) \\
29(20.6)\end{array}$ & $\begin{array}{c}1.03[0.66 ; 1.63] \\
\text { ref. }\end{array}$ & - \\
\hline $\begin{array}{l}\text { Wealth index } \\
\text { Poor } \\
\text { Middle } \\
\text { Rich }\end{array}$ & $\begin{array}{l}87(75.7) \\
44(77.2) \\
96(83.5)\end{array}$ & $\begin{array}{l}28(24.3) \\
13(22.8) \\
19(16.5)\end{array}$ & $\begin{array}{l}1.47[0.88 ; 2.53] \\
1.38[0.71 ; 2.57] \\
\text { ref. }\end{array}$ & $\begin{array}{c}2.07[1.06 ; 4.07] \\
1.72[0.80 ; 3.56] \\
-\end{array}$ \\
\hline $\begin{array}{l}\text { Married or cohabitation } \\
\text { Yes } \\
\text { No }\end{array}$ & $\begin{array}{l}126(85.1) \\
101(72.7)\end{array}$ & $\begin{array}{l}22(14.9) \\
38(27.3)\end{array}$ & $\begin{array}{c}0.54[0.33 ; 0.86] \\
\text { ref. }\end{array}$ & $\begin{array}{c}0.72[0.40 ; 1.24] \\
\text { ref. }\end{array}$ \\
\hline $\begin{array}{l}\text { Education } \\
\text { Primary or no education } \\
\text { Secondary } \\
\text { Secondary professional/Higher }\end{array}$ & $\begin{array}{l}80(77.7) \\
106(76.8) \\
41(89.1)\end{array}$ & $\begin{array}{c}23(22.3) \\
32(23.2) \\
5(10.9)\end{array}$ & $\begin{array}{l}2.05[0.91 ; 5.82] \\
2.13[0.98 ; 5.96] \\
\text { ref. }\end{array}$ & $\begin{array}{l}- \\
- \\
-\end{array}$ \\
\hline $\begin{array}{l}\text { Employment } \\
\text { Officially employed } \\
\text { Unofficially employed or not employed }\end{array}$ & $\begin{array}{c}94(80.3) \\
133(78.2)\end{array}$ & $\begin{array}{l}23(19.7) \\
37(21.8)\end{array}$ & $\begin{array}{c}\text { ref. } \\
1.11[0.70 ; 1.79]\end{array}$ & $\begin{array}{l}- \\
-\end{array}$ \\
\hline $\begin{array}{l}\text { Labor migration } \\
\text { Yes } \\
\text { No }\end{array}$ & $\begin{array}{c}39(78.0) \\
188(79.3)\end{array}$ & $\begin{array}{l}11(22.0) \\
49(20.7)\end{array}$ & $\begin{array}{c}1.06[0.56 ; 1.81] \\
\text { ref. }\end{array}$ & $\begin{array}{l}- \\
-\end{array}$ \\
\hline $\begin{array}{l}\text { Medical insurance status before } \mathrm{TB}^{\circ} \\
\text { Yes } \\
\text { No }\end{array}$ & $\begin{array}{l}106(83.5) \\
119(76.8)\end{array}$ & $\begin{array}{l}21(16.5) \\
36(23.2)\end{array}$ & $\begin{array}{c}0.71[0.43 ; 1.14] \\
\text { ref. }\end{array}$ & $\begin{array}{l}- \\
-\end{array}$ \\
\hline
\end{tabular}


time, the causal pathway between poverty and unfavourable TB treatment outcomes is complex and involved multiple additional factors. Some studies determined that the accumulated psychosocial stress caused by sickness may be one plausible biological mechanism explaining the increased odds of poor TB treatment outcome among patients with low socioeconomic status [31,32].

Living in an urban area was identified as a risk factor for an unfavourable outcome such as loss to follow-up for the RR/MDRTB patients in the study conducted in the Republic of Moldova in 2019 [33]. In our study living in an urban area was independently associated with unfavourable outcome. The poverty assessment reports $[34,35]$ highlight on continuing differences in the standard of living between urban and rural populations, with the level of poverty in rural areas being higher than in urban areas. On the other hand, the rural population have access to non-financial resources (own livestock and garden) in comparison with the urban population and may be less dependent on wages [34]. One of the additional explanations can be that during the years, community services (information, education, peer support, adherence programs) has been more concentrated in rural areas considering that rural area has less access to medical services [36].

As expected, patients with TB/HIV coinfection to have higher rates of unfavourable TB outcomes. A survey conducted on financial burden of HIV and TB among patients in Ethiopia [37] revealed that TB patients face TB-related costs during the treatment and after treatment completion, TB patients are less likely to face additional costs while people living with HIV face costs over their lifetime because HIV infection is a chronic disease that needs lifelong treatment. This fact could influence TB treatment results as well. Usually, HIV-positive patients are more likely than HIV-

Table 3. Continued from previous page.

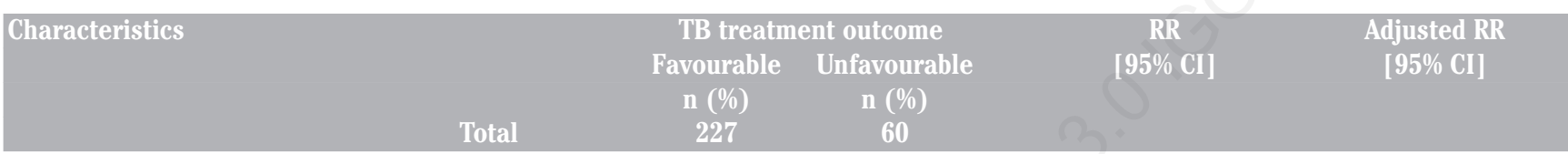

History of imprisonment ${ }^{\circ}$

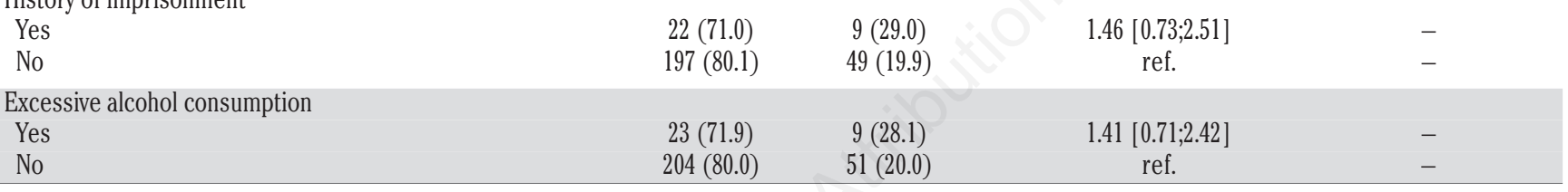

HIV status

Negative

Positive

Presence of diabetes mellitus

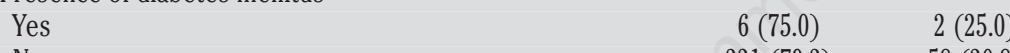

Nype of TB case

New
Retreatment

Presence of side-effects during TB treatment

Yes

No

Perceived needs - family support ${ }^{\circ}$

Yes

No

Perceived needs - better alimentation ${ }^{\circ}$

Yes

No

Perceived treatment barriers - smoking ${ }^{\circ}$

Yes

No

Perceived treatment barriers - side effects ${ }^{\circ}$

Yes

No

Perceived concerns - treatment without effect ${ }^{\circ}$

Yes

No

Perceived concerns - spread TB to my family ${ }^{\circ}$

Yes

No

Missing data was excluded: medical insurance status before $\mathrm{TB}(\mathrm{n}=2)$; history of imprisonment $(\mathrm{n}=8)$; perceived needs, famil

side effects $(\mathrm{n}=20)$; perceived concerns, treatment without effect or spread TB to my family $(\mathrm{n}=45)$; HIV, human immunodeficiency viruses; RR, relative risk; ref., reference category; CI, confidence interval; TB, tuberculosis; RR/MDR, rifampicin resistant or multi-drug resistant tuberculosis. Descriptive statistics were summarized as n (\%).

$47(17.9)$

$13(52.0)$

$221(79.2)$

$58(20.8)$

$152(80.4) \quad 37(19.6)$

$75(76.5)$

23 (23.5)

ref.

2.90 [1.74;4.42]

ref.

$2.61[1.31 ; 4.89]$

.20 [0.22;2.97]

ref.

$-$

ref.

1.20 [0.74;1.88]

$193(79.1) \quad 51(20.9)$

$34(79.1) \quad 9(20.9)$

1.00 [0.57;2.03] ref.

$-$

$121(80.7) \quad 29(19.3)$

91 (75.2)

30 (24.8)

$163(77.6) \quad 47(22.4)$

$49(80.3) \quad 12(19.7)$

0.78 [0.49;1.23]

ref.

1.14 [0.67;2.12] ref.

$87(74.4) \quad 30(25.6)$

$120(80.5)$

$29(19.5)$

1.32 [0.84;2.08]

$$
\text { ref. }
$$

$99(78.0)$

28 (22.0)

$31(22.3)$

$0.99[0.63 ; 1.55]$ ref.

$-$

$84(73.0) \quad 31(27.0)$

98 (81.7)

$22(18.3)$

$1.47[0.91 ; 2.42]$

ref.

$\begin{array}{ccc}95(82.6) & 20(17.4) & 0.63[0.38 ; 1.02] \\ 87(72.5) & 33(27.5) & \text { ref. }\end{array}$

$-$ $-$

$-$ RI] 
negative patients to have extrapulmonary TB or smear-negative pulmonary TB [38]. This may lead to a delay in TB diagnosis and treatment initiation, increasing the chance of unfavourable outcomes and the patient may face additional costs during in pre-treatment period. Delayed TB diagnosis and later initiation of RR/MDR-TB treatment can also affect the outcome of treatment [33]. TB and HIV drugs must be supplemented with higher food intake $[39,40]$. It has been suggested that HIV positive TB patients are more likely to become malnourished due to constant sickness [41], which can be associated to unfavourable treatment results. Another reason for unfavourable outcomes among HIV-associated TB patients could be poor uptake of anti-retroviral therapy and death due to HIV-related causes [42].

There are some limitations in this study related to the parent study methodology: first the use of self-reported data on respondent's income and expenditures, then not taking into account the time spent (for medical consultations, investigations, or to pick up medicines from the treatment site) and the study population. The criteria for enrolment in the baseline study (RR/MDR-TB patients who were in inpatient or outpatient TB care for at least for 2 months for intensive and continuation phases, respectively) led to an overestimation of favourable outcomes, given one third of deaths among TB patients occur within the first two months of treatment $(27 \%)$. In our study the proportion with successful outcome was higher $(79 \%)$ than the treatment success rate of $60 \%$ reported by NTP for Right Bank of the Dniester River (without penitentiaries) for 2016 cohort.

\section{Conclusions}

In the Republic of Moldova, we failed to find an association between catastrophic costs and treatment outcomes of RR/MDRTB patients. However, our study found that patients from poor households were twice more likely to experience unfavourable TB treatment outcomes regardless of whether they experienced TB catastrophic costs or not. Also, TB/HIV patients and urban residents were identified as the most vulnerable groups with higher risk of unfavourable treatment outcome. The patient-centred care approach and expanded social and financial risk protection measures are needed to minimise the high patient cost of TB care and improve treatment outcomes in special groups such as coming from poverty households, living in urban area, and having TB/HIV coinfection.

\section{References}

1. WHO Regional Office for Europe. Defining the tuberculosis research agenda for the WHO European Region: a study report of the European TB Research Initiative. Geneva: World Health Organisation; 2019. Accessed on: 2020 Jul 7. Available from: https://www.euro.who.int/en/publications/abstracts/definingthe-tuberculosis-research-agenda-for-the-who-european-regiona-study-report-of-the-european-tb-research-initiative-2019

2. WHO, The World Bank. Tracking universal health coverage: first global monitoring report. Geneva: World Health Organization; 2015. Accessed on: $2020 \mathrm{Jul} 7$. Available from: https://apps.who.int/iris/bitstream/handle/10665/174536/97892 41564977_eng.pdf?sequence $=1$

3. WHO. Health in 2015: From MDGs, Millennium Development
Goals To SDGs, Sustainable Development Goals. Geneva: World Health Organization; 2015. Accessed on: 2020 Jul 7. Available from: https://apps.who.int/iris/bitstream/handle/ 10665/200009/9789241565110 eng.pdf?sequence=1

4. Xu K, Evans DB, Carrin G, et al. Protecting households from catastrophic health spending. Health Affairs 2007;26: 972-83.

5. WHO. End TB strategy. Global strategy and targets for tuberculosis prevention, care and control after 2015. Geneva: World Health Organisation; 2015. Accessed on: 2020 Jul 2. Available from: http://www.who.int/tb/strategy/en/

6. WHO. Tuberculosis patient cost surveys: a handbook. Geneva: World Health Organization; 2017. Available from: https://www. who.int/tb/publications/patient_cost_surveys/en/

7. The Word Bank. World Bank Open Data. Accessed on: 2020 Jun 30. Available from: https://data.worldbank.org/indicator/sh. xpd.oopc.ch.zs?locations $=\mathrm{md}$

8. The World Bank. Republic of Moldova - Country context. 2019 Accessed on: 2019 Nov 11. Available from: https:/www.worldbank.org/en/country/moldova/overview

9. Tanimura T, Jaramillo E, Weil D, et al. Financial burden for tuberculosis patients in low- and middle-income countries: a systematic review. Eur Res J 2014;43:1763-75.

10. WHO. Use of high burden country lists for TB by WHO in the post-2015 era. Geneva: World Health Organization; 2015 Accessed on: $2020 \mathrm{Jul}$ 7. Available from: https://www.who.int/ tb/publications/global_report/high_tb_burdencountrylists20162020.pdf

11. Dadu A, Hovhannesyan A, Ahmedo S, et al. Drug-resistant tuberculosis In Eastern Europe and Central Asia: a time-series analysis of routine surveillance data. Lancet Infect Dis 2019;20:250-8.

12. WHO Regional Office for Europe. Roadmap to implement the tuberculosis action plan for the WHO European Region 20162020. Towards ending tuberculosis and multidrug-resistant tuberculosis (2016). Geneva: World Health Organization; 2016. Accessed on: $2020 \mathrm{Jul} 1$. Available from: https://www. euro.who.int/en/publications/abstracts/roadmap-to-implement-the-tuberculosis-action-plan-for-the-who-europeanregion-20162020.-towards-ending-tuberculosis-and-multidrug-resistant-tuberculosis-2016

13. Republic of Moldova. Government Decision No. 1160 dated 20 October 2016, on the approval of the National Tuberculosis Control Program (NTP) for the years 2016-2020. Available from: http://lex.justice.md/viewdoc.php?action=view\&view= doc\&id=367268\&lang $=1$

14. WHO Regional Office for Europe. Analysis of the epidemiological impact of tuberculosis in the Republic of Moldova. Geneva: World Health Organization; 2017. Accessed on: 2020 Jul 7. Available from: http://www.euro.who.int/_data/assets/ pdf_file/0011/337853/moldova_epi_review_final.pdf?ua=1

15. Ministry of Health of the Republic of Moldova. Sime TB Moldova National Database for Notification and Follow-Up on Tuberculosis Cases. Accessed on: 2020 Jul 7. Available from: http://simetb.ifp.md/

16. Ciobanu A, Plesca V, Barba O, et al. Assessment of multidrugresistant tuberculosis associated catastrophic costs incurred by families/households in the Republic of Moldova. 2017. Accessed on: $2020 \mathrm{Jul}$ 1. Available from: https://www. researchgate.net/publication/321051278_assessment_of_multidrug-resistant_tuberculosis_associated_catastrophic_costs incurred_by_familieshouseholds_in_the_republic_of_moldova

17. Barter $\overline{\mathrm{DM}}$, Agboola SO, Murray $\overline{\mathrm{MB}}$, Bärnighausen $\mathrm{T}$. Tuberculosis and poverty: the contribution of patient costs in 
Sub-Saharan Africa - a systematic review. BMC Public Health 2012;12:980.

18. Ananthakrishnan R, Muniyandi M, Jeyaraj A, et al. Expenditure pattern for TB treatment among patients registered in an urban government DOTS program in Chennai City, South India. Tub Res Treat 2012;2012:747924.

19. Ukwaja KN, Alobu I, Abimbola S, Hopewel PC. Household catastrophic payments for tuberculosis care in Nigeria: incidence, determinants, and policy implications for universal health coverage. Infect Dis Poverty 2013;2:21.

20. Ukwaja KN, Alobu I, Hopewell PC, et al. The high cost of free tuberculosis services: patient and household costs associated with tuberculosis care in Ebonyi State, Nigeria. Plos One 2013;8:e73134.

21. Mauch V, Bonsu F, Gyapong M, et al. Free tuberculosis diagnosis and treatment are not enough: patient cost evidence from three continents. Int J Tuberc Lung Dis 2013;17:381-7.

22. Hanson CL, Weil DE, Floyd K. Tuberculosis in the poverty alleviation agenda. In: L.B. Reichman, E.S. Hershfield, editors. Reichman and Hershfield's Tuberculosis. CRC Press; 2006. p. 1147-64.

23. Rajeswari R, Balasubramanian R, Muniyandi M, et al. Socioeconomic impact of tuberculosis on patients and family in India. Int J Tuberc Lung Dis 1999;3:869-77.

24. WHO Regional Office for Europe. Definitions and reporting framework for tuberculosis - 2013 revision (updated December 2014). Geneva: World Health Organization; 2014. Accessed on: $2020 \mathrm{Jul}$ 7. Available from: https://apps.who.int/iris/bitstream/ handle/10665/79199/9789241505345_eng.pdf

25. Ciobanu A, Domente L, Soltan V, et al. Do incentives improve tuberculosis treatment outcomes in the Republic of Moldova? Public Health Action 2014;4:S59-63.

26. World Bank. FAQs: Global poverty line update. Accessed on: 2020 Jul 7. Available from: https://www.worldbank.org/en/ topic/poverty/brief/global-poverty-line-faq

27. Pirani E. Wealth Index. In: A.C. Michalos, editor. Encyclopedia of Quality of Life and Well-Being Research. Dordrecht: Springer; 2014. p. 7017-8.

28. Wingfield T, Boccia D, Tovar M, et al. Defining catastrophic costs and comparing their importance for adverse tuberculosis outcome with multi-drug resistance: a prospective cohort study, Peru. Plos Med 2014;11:e1001675.

29. Djibuti M, Mirvelashvili E, Makharashvili N, Magee MJ. household income and poor treatment outcome among patients with tuberculosis in Georgia: a cohort study. BMC Public Health 2014;14:88

30. WHO. Barriers and factors facilitating access to health services in the Republic of Moldova. Geneva: World Health Organisation; 2012. Accessed on: 2020 Jul 8. Available from: https://www.euro.who.int/_data/assets/pdf_file/0018/183510/ e96775-final.pdf

31. Peltzer K, Naidoo P, Matseke G, et al. Prevalence of psychological distress and associated factors in tuberculosis patients in public primary care clinics in South Africa. BMC Psychiatry 2012;12:89.

32. Kristenson M Eriksen HR, Sluiter J K, et al. Psychobiological mechanisms of socioeconomic differences in health. Soc Sci Med 2004;58:1511-22.

33. WHO, Gulpe T, Ciobanu A, et al. Risk factors associated with loss to follow-up among multidrugresistant tuberculosis patients in the Republic of Moldova in 2014-2016. Public Health Panorama 2019;5 $\square: 493-502$.

34. Ministry of Economy of the Republic of Moldova. Poverty report, Republic of Moldova. 2011. Accessed on: $2020 \mathrm{Jul} 8$. Available from: https://mei.gov.md/sites/default/files/povertyreport-republic-of-moldova-2010-2011.pdf?attempt=1\&status $=4$

35. United Nations Development Programme (UNDP) in the Republic of Moldova. Inequalities and sustainable human development in Moldova. UNDP 2017. Accessed on: $2020 \mathrm{Jul}$ 8. Available from: https://www.md.undp.org/content/moldova/en/home/library/human_development/nhdr-2016.html

36. Van Hest NA, Aldridge RW, De Vries G, et al. Tuberculosis control in big cities and urban risk groups in the European Union: a consensus statement. Euro Surveill 2014;19:20728.

37. Assebe LF, Negussie EK, Jbaily A, et al. Financial burden of HIV and TB among patients in Ethiopia: a cross-sectional survey. BMJ Open 2019;10:e036892.

38. WHO. Tuberculosis care with TB-HIV co-management. Geneva: World Health Organization; 2007. Accessed on: 2020 Jul 8. Available from: https://www.who.int/hiv/pub/imai/TB HIVModule23.05.07.pdf

39. Food and Nutrition Technical Assistance. HIV/AIDS: a guide for nutrition, care and support. 2001. Accessed on: $2020 \mathrm{Jul} 8$. Available from: https:/www.who.int/hac/techguidance/pht/ 8518.pdf

40. WHO. Guideline: nutritional care and support for patients with tuberculosis. Geneva: World Health Organization; 2013. Accessed on: 2020 Jul 8. Available from: https://www.who. int/nutrition/publications/guidelines/nutcare_support_patients with_tb/en/

41. Babameto G, Kotler DP. Malnutrition in HIV infection. Gastroenterol Clin North Am 1997;26:393-415.

42. Odone A, Amadasi S, White RG, et al. The impact of antiretroviral therapy on mortality in HIV positive people during tuberculosis treatment: a systematic review and meta-analysis. Plos One 2014;9:E112017. 